УДК 572; ББК 28.71; DOI https://doi.org/10.21638/spbu19.2018.208

M. Filip

\title{
A TRIBE AFTER ALL? \\ THE PROBLEM OF SLOVINCIANS' IDENTITY IN AN ANTHROPOLOGICAL APPROACH
}

The identity of Slovincians ${ }^{1}$ is a subject of a wide range of controversies in the field of Slavic studies. The root of the conflict between supporters of the ethnic distinctiveness of Slovincians, and opponents who suggest Slovincians are a part of the Kashubian ethnic group (and thus an ethnographic group), is the past work of Aleksandr Hilferding ${ }^{2}$, a Russian linguist and ethnographer who was the first to describe this group's history and culture. He claimed that Slovincians and Kashubians were the last Slavs on the southern shore of the Baltic Sea to oppose Germanisation since early medieval. Hilferding's theses were the basis of the canonical history of Slovincians, in which this ethnic group had roots to a tribe of the same name. In the middle of the $19^{\text {th }}$ century, Slovincians living between Lake Gardno and Lake Łebsko were indeed the westernmost group of Slavs living in Pomerania, or more precisely on the eastern frontier of western Pomerania (ger. Hinterpommern). They commonly switched to the German language and assimilated a German ethnic identity as late as the start of the $20^{\text {th }}$ century. As a consequence, Slovincians who found themselves living in Poland after World War II were seen as Germans and were subjected to displacement by settlers and administrators of the region. The Polish intellectual elite, however, did not forget about the Slavic origin of the region's inhabitants and demanded leaving them on the Polish soil and suggested their re-Slavisation, or de facto Polonisation. Sadly, only a tiny part of that society, living in the village of Kluki, was saved from displacement, and the Polonisation of the group had little success due to majority of Slovincians relocating in the $20^{\text {th }}$ century to Germany.

Such a vision of Slovincian history and calling them a "tribe" or "ethnic group" has bred doubt amongst scholars. Using archival materials and, to a lesser extent, archeological

${ }^{1}$ I have dealt more fully with the identity of Slovincians in: Filip M. Od Kaszubów do Niemców. Tożsamość Słowińców z perspektywy antropologii historii. Poznań, 2012

${ }^{2}$ Гильфердинг A. Ф. Остатки Славян на южном берегу Балтийского Моря. СПб., 1862; Hilfer$\operatorname{ding}$ A. Ostatki Słowian na południowym brzegu Bałtyckiego Morza // Pomorze / Red. O. Kolberg. Kraków, [Warszawa], 1965. P. 311-452.

(C) M. Filip, 2018

$\overline{\text { 2018. № } 2 \text { (24). Июль-Декабрь }}$ 
materials, historian Zygmunt Szultka claimed ideas that modern Slovincians, as well the medieval tribe of Slovincians, are but an imagination of scholars ${ }^{3}$. It is not an original thesis, since as early as the beginning of $20^{\text {th }}$ century two German researchers dubbed Slovincians a "Pan-Slavonic fraud"4, but due to ideology, this claim was not broadly recognized by Polish researchers, and another Slavist, Friedrich Lorenz ${ }^{5}$, did not support it, either. In a different political environment and with the support of rich evidence, Szultka's theses were more readily accepted. Linguist Jerzy $\operatorname{Treder}^{6}$ (2003) defended the thesis of the Slovincians' ethnic distinctiveness up to his death.

While canonical history describes Slovincians as a people like the Kashubians, revisionist historiography states that the Slovincians are a branch of the Kashubians. For revisionists the first interpretation is false and only the second provides the history wie es eigentlich gewesen [as was indeed]. While for supporters of Slovincians' ethnic distinctiveness, both groups are facts, for its opponents only the Kashubians are fact, while Slovincians are fiction, a myth, delusion, untrue. It is emblematic that German scholars think of Slovincians as a Slavonic fraud, while in contrast, Szultka claimed that German pastors are responsible for creating this myth. If Slovincians were a fiction, the Slovincians should not exist, contrary to the Kashubians, whose existence is indisputable. Refusing the reality of the Slovincians while not arguing against the existence of the Kashubians prompts questions about the essence of the relation between the two groups as well as about rationale of these connected theses.

\section{THE NAME (FROM ETHNONYM TO EXONYM)}

The dispute over the (non)existence of Slovincians is to a large extent only a matter of words. This started over a record: "And thus, the so-called Kashubians are known as Stowienci in Western Pomerania" ("So nennen sich die so genannten Kassuben in Pommern Stowienci"), by German Sorabist Karl Gottlob von Anton ${ }^{7}$. The matter of whether the Kashubians really called themselves this, what the meaning of this word was, and in what exact form it was used, seems irresolvable. I suggest that it is more important that the mentioned name (signifiant) is a designator of something (signifié) and creates a notion of Slovincians as a people. The act of linguistic creation or inclusion of Slovincians into the language game made them a subject of scholarly interest (or basically a scientific problem), because it is the logos that is "the principle of the universe and the first principle of human knowledge".

${ }_{3}^{3}$ Szultka Z. Studia nad rodowodem i językiem Kaszubów. Gdańsk, 1992.

${ }^{4}$ Koblischke J. Der Name "Slovinzen" // Mitteilungen des Vereins für Kaschubische Volkskunde. 1908. Vol. 1. No 1. P. 12-14; Knоop O. Etwas von den Kaschuben // Unsere Heimat. Beilage zur Kösliner Zeitung. 1925. No. 1 (January 31), no. 2 (February 21), no. 4 (March 28), no. 6 (April 27). ${ }^{5}$ Lorentz F. Nochmals der Name "Slovinzen" // Mitteilungen des Vereins für kaschubische Volkskunde. 1908. Vol. 1. No 1. P. 14-16

${ }^{6}$ Treder J. Komu może przeszkadzać etnonim Słowińcy? // Obrazy Ziemi Słupskiej. Społeczeństwo - administracja - kultura. Materiały z VII Konferencji Kaszubsko-Pomorskiej, Słupsk 5-6 grudnia 2002 / Ed. by A. Czarnik. Słupsk, 2003. P. 59-70.

${ }^{7}$ Anton K. G., von. Erste Linien eines Versuches über die alten Slawen Ursprung, Sitten, Gebräuche, Meinungen und Kenntnisse. Mit zwey Kupfern. Leipzig, 1783. P. 22. (Regarding transformation and history of this name see e.g.: Дуличенко А. Д. К незатухающему спору о словинцах (еще один скромный голос) // Rocznik Gdański. 1995. Vol. 55. No 1. P. 83-91.)

${ }^{8}$ Cassirer E. An Essay on Man. An Introduction to a Philosophy of Human Culture. New York, 1944. P. 144-145. 
In light of modernist science's assumptions, language reflects reality. In a radical (naive) version of this belief, represented mainly by Hilferding and Treder, a complete equality of word and object is assumed: it is impossible for one to exist without the other. The existence of the word "Slovincians" is proof that Slovincians exist as a people. Although there is no evidence for existence of this name before 1783 or of such an ethnic group, such scholars assume that it had to be so. In their opinion, the terms present in old Kashubian-Polish prints, and even the name of the town of Sławno, prove the existence of the name "Slovincians," and thus of Slovincians themselves in the past.

Opponents of the argument for the existence of Slovincians, Koblischke, Knoop and Szultka, represent a more moderate (critical) view on the connection between names and objects. They believe that objective description of the world by usage of language (names) is possible, but it is a scholar's duty to determine which names describe reality, which are true, and which are false. The reality of names is not determined on the basis of philological research, research of the language alone, but through research of the extralingual reality: age, circumstances of creation and usage, assigned (not etymologically derived) meaning, and so on. The word "Slovincians" is only an argument supporting and not proving the existence of Slovincians. They believe that a discrepancy between a name and an object occurs: would be Slovincians are not an ethnic group, because the history of said name only arises at the turn of the $19^{\text {th }}$ century and reveals a foreign origin; moreover, there are no people who referred to themselves by this name ${ }^{10}$. If the name "Slovincians" was only used by intellectual elites, it means that Slovincians are simply a made-up group and do not exist. The name correctly describing a disputed collectivity of people should be "Kashubians", which is clearly stated by the title of the treatise of the main opponents to the Slovincians' existence.

While I agree with the critics, that the existence of the name "Slovincians" does not necessarily mean the existence of an ethnic group of Slovincians, I cannot refrain from pointing out the weaknesses of hidden assumptions in the revisionists' methodology. First, it is an assumption of ethnic conditioning of identity. It is assumed that humanity is divided into ethnic groups, humans are conscious about their identity (ethnicity), and they name this correctly. If Slovincians were an ethnic group, all its members would be conscious of it and would strongly articulate it together. However, what seems not known by revisionists is that ethnicity is not the only mode for social or cultural organization. There are many groups that do not see the need to verbalise their identity with particular words, and if they do so, they are not necessarily unanimous about which word. Thus, it is possible for Slovincians to exist as a group, without a strong declaration of this by using an ethnonym (endonym).

${ }_{9}^{9}$ Krofey S. Duchowne piesnie D. Marcina Luthera y ynßich naboznich męzow. Zniemieckiego w Slawięsky ięzik wilozone. Gdainsk, 1586; Pontanus M. Parvus Catechismus D. Martini Lvtheri Germanica - Vandalicus $=$ Der kleine Catechißmus D. Martini Lutheri $/$ Deutsch vnnd Wendisch gegen einander gesetzt. Mit anhange der Sieben Bußpsalmen König DAVIDS = Mały Catechism D Marciná Lutherá Niemeicko Wándalski ábo Słowięski / to jestá z Niemeickiego języká w Słowięski wystáwion y ná jáwnosc wydan / Z Przydatkiem Siedm Psálmow Pokutnych krolá DAWIDA y inßych Potrzebnych rzeczi: osobliwie Historiy Passiy náßego Páná JESVSA według Ewángelistá MATTHEVßá / y niektorych Piesn duchownych. Gdainsk, 1643.

${ }^{10}$ The idea that only subjectively recognized names (endonyms) can demand to be "objective" names (ethnonyms) is clearly visible here. 
Second, there is the assumption that truth is a function of time, which means that the reality of things is conditioned by their age. This is the derivative of the belief that things exist in the world naturally, and so they "have always existed". Only those things are authentic (important) that have an "ancient" origin or, even better, whose origins fade into the dusk of the past. Things for which the long tradition cannot be presented are taken as unnatural, fake, unreal, or made up. If Slovincians were an ethnic group, they would have been one "since time immemorial", and thus since early medieval times (primordialism). In the meantime, age is not an irrespective quality. What is old today was not old in the past. Thus, the fact, that the name Slovincian is younger than the name Kashubians does not necessarily mean the latter group is objectively closer to reality. In essence, it is impossible to determine validity of the names and things based on their age.

Philological research has aimed to helpsettle the question of Slovincians' status by determining whether the Slovincian ethnolect' is truly a language (ethnic group) or merely a dialect of Kashubian (ethnographic group), and at first glance it seems to support revisionists' ideas. The thesis of Slovincian linguistic distinctiveness did not survive the test of time, however, and does not help answer the question of Slovincians' identity. First, the difference between a dialect and a language is conventional (socially constructed), a prime example of which can be Kashubian itself: the conflict over its status in language classification (language or dialect) is far from resolved. Second, there is no direct relation between ethnicity and language, as examples of different ethnic groups using the same language are known, as well as examples of different languages being used by the same ethnic group.

Taking this into consideration, I suggest that the problem of Slovincian identity should be reconsidered once again. At the beginning, the question about the Slovincians' distant history must be raised. Is Slovincians" "ethnogenetic" process really different than that of the Kashubians in its quality? Does the nonexistence of Slovincians in the early medieval period exclude their existence in modern times? If not, then how did the Slovincians exist, and did they exist at all?

\section{History (NATURAList NOTION OF A TRIBE)}

One of the key arguments supporting the thesis of the Slovincians being a fiction is the neglect of this tribe's existence in medieval works: "In reality, the so-called Slovincians never existed as a tribal group or a remnant, nor did they as a dialect group significantly differ genetically from other Kashubian peoples from east of Western Pomerania"11. My aim here is only to consider the premises of this thesis and its real implications. Szultka and Hilferding agree that in the early medieval period there were some tribes living in Pomerania; only the autonomy of the population living between Lake Gardno and Lake Lebsko is argued. According to Hilferding this population composed a separate tribe, the Slovincians; according to Szultka, it was only "a part of a tribe of Kashubians". I will try to show that Szultka's findings are in no way conclusive: not only the argumentation, but mainly the very shallow understanding of a notion of tribe leaves much to be desired. In fact, Szultka, like Hilferding a century before him, never defines it. However, contrary to the latter, who freely applied it both past and present, to all Slavs in general as well as to specific Slavic peoples, the former limits it to the past and archeologically defined geographic regions. I will risk the claim that

\footnotetext{
${ }^{11}$ Szultka Z. Studia... P. 78-79.
} 
Szultka would approve of this archeological definition of a tribe: "a synonym of regional and local communities living in the Polish (sic!) lands between the $7^{\text {th }}$ and mid- $9^{\text {th }}$ centuries with names established in written sources and/or identified by the results of archaeological investigations" ${ }^{\prime 2}$. As an anthropologist I feel obligated to note that distance in time, which is contained in such a definition of "tribe," is "an invention" of late $19^{\text {th }}$ century historical research, because the first scientific definition of a tribe - formed in the field of anthropology as a "completely organized society... individualized by a name, by a separate dialect, by a sovereign government and by the possession of territory which it occupies and defends as its own"13 — was characterised more by a spatial distance, and, even more, it marked not only by territory and the name, but also by language, which Szultka separates. I do not mention it to prove that the older definition is closer to the truth - which should be done following the line of Szultka's argument - but because tribality is not simply a matter of time or settlement, but of many other qualities. What escapes Szultka's view is not only the matter of kinship, in particular descent - a key matter for the notion of a tribe ${ }^{14}$ but also research from political anthropology, which has produced the famous neo-evolutionist scheme: horde, tribe, chiefdom, state ${ }^{15}$. Denying Slovincians' status as a tribe requires proving that their society is not a noncentralised, egalitarian system (dispersed power), in which kinship fulfil the basic role of integration; Szultka completely ignores this, concentrating on settlement, which can be explained with hidden (stricte archeological) assumptions about the tribe, as well as limited possibilities to verify the thesis of the Slovincians as a tribe. Since we have to leave aside the matter of political organization and kinship, let us look closer at Szultka's thinking.

His argumentation is oriented to negating statements by pastor A.T. Kummer's and by A. Hilferding, in particular that the Pustynka stream is a tribal border. Szultka's argument that its size made it irrelevant for organizing parishes and settlements ${ }^{16}$, is based on the assumption that natural borders define social borders. Referring to archaeological research, Szultka proves that the "area occupied in $19^{\text {th }}$ century by so called Slovincians and Kabatians (i.e. Germ. Kabatker) was inhabited by one relatively small tribe, similar in size to tribal organization from middle course of the Wieprza and Grabowa, as early as the $7^{\text {th }}$ century. The line dividing them ran between the Stupia and Grabowa rivers, and not along the Pustynka stream." From the $9^{\text {th }}$ to $10^{\text {th }}$ centuries, the above-mentioned tribe had "taken new grounds in the direction of the seashore," meaning that "already then, the Pustynka stream was not a border of the tribe's development, but on the contrary, the area between the middle and lower course of the Lupawa and Leba was a one densely populated strip of land"17.

According to archaeologists, the tribes from the Słupia-Łupawa- $€$ eba basin and the Wieprza-Grabowa basin are parts of "a bigger settlement system of Danzig Pomerania (and not Western Pomerania), whose western border overlapped with the border of the WieprzaGrabowa basin, and ran more or less along the Uniesta river (actually Unieść. — M. F.), and

${ }_{12}$ Buko A. The Archaeology of Early Medieval Poland. Discoveries - Hypotheses Interpretations. Leiden \& Boston, 2008. P. 76, annot. 2.

${ }^{13}$ Morgan L. H. Ancient Society. Chicago, 1877. P. 102, 120.

${ }^{14}$ Linguistically, this is more visible in Slavic languages than in English: consider the relation of e.g. Polish words plemie and plemnik (tribe and sperm).

${ }^{15}$ Evolution and Culture / Ed. by M. D. Sahlins, E. R. Service. Ann Arbor, 1960.

${ }^{16}$ Szultka Z. Studia... P. 69, 77-79.

${ }^{17}$ Szultka Z. Studia... P. 79-80. 
which on the east closed in on the line of the Vistula". This allows Szultka to declare that "shaping the early feudal state organizations from the $11^{\text {th }}$ to the $12^{\text {th }}$ centuries, between Chełmska Hill to the west and the river Leba to the east, did not cause fragmentation of tribal and linguistic community from between Łupawa and Łeba, which developed west, to the course of the Słupia. (...) in this area a small tribal community called Slovincians did not emerge" 18 .

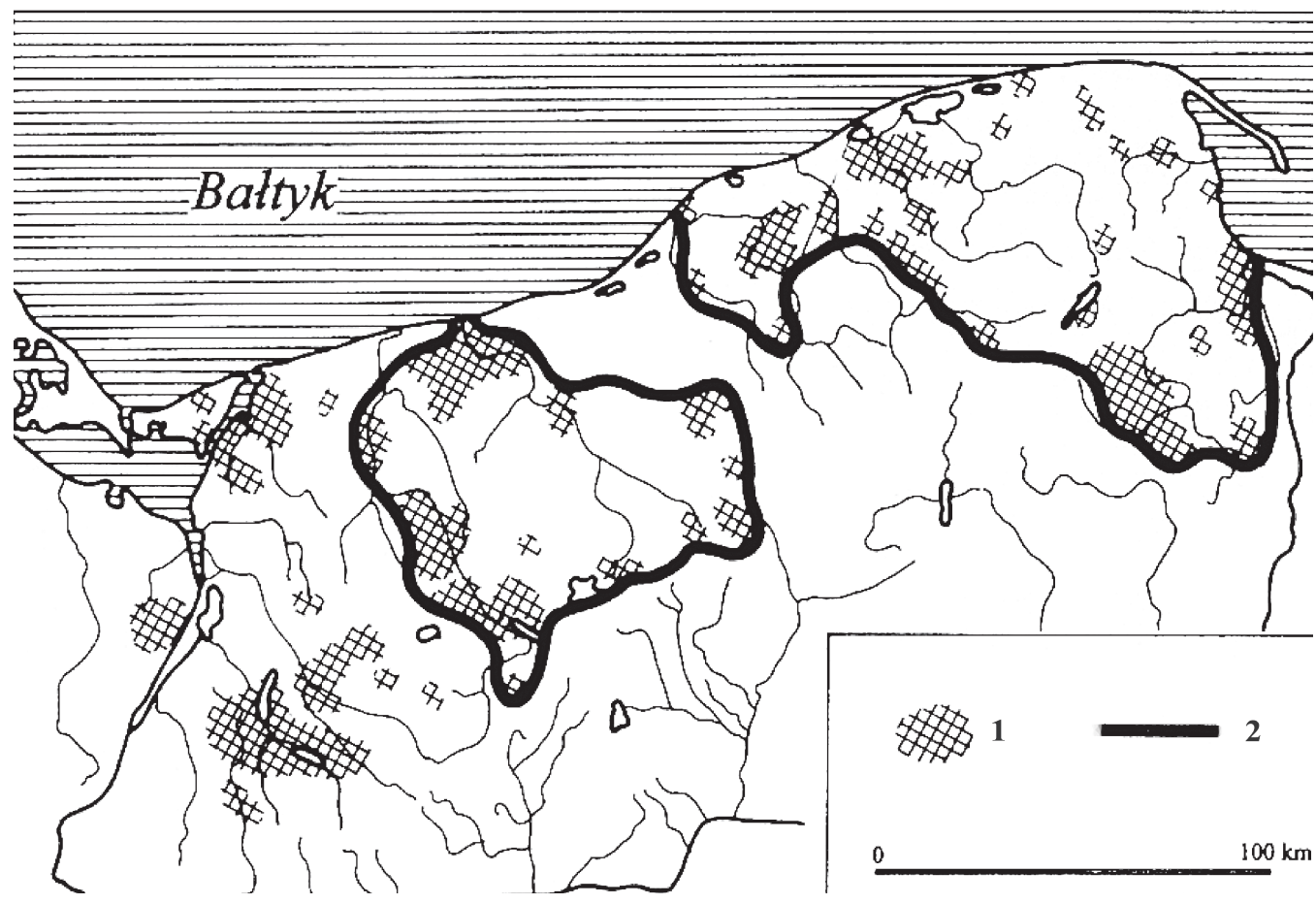

Figure 1. Assumed great tribes in Pomerania in the $7^{\text {th }}$ to $8^{\text {th }}$ centuries on the background of small tribal organisms, according to W. Łosiński (Osadnictwo plemienne. P. 197.)

1 - small tribes; 2 - assumed borders of great tribes

What emerges from Szultka's revelation? While the thesis of Pustynka not being an important natural border is valid, conclusions about social organization made on its basis are inappropriate. On a logical level, concluding the (non)existence of the Slovincians on the grounds that a border between them and another group was not in a specific place, as a reduction, is misleading: this is akin to arguing that if the Volga is not Russia's border, then Russia does not exist. On a substantive level, the approach of (objectively) claiming that natural borders determine (subjective) identity borders duplicates Johann Gottfried Herder's ${ }^{19}$

${ }^{18}$ Szultka Z. Studia... P. 80.

${ }^{19}$ Herder J. G. J. G. Herder on Social and Political Culture. London, 1969; por. Wimmer A. Herder's heritage and the boundary-making approach: studying ethnicity in immigrant societies // Sociological Theory. 2009. Vol. 27. No 3. P. 244-270. 
exquisitely naturalist approach and stands in contradiction to antinaturalist approaches to identity, with Frederik Barth's ${ }^{20}$ ecology of ethnicity being the prime example.

Lack of a separate settlement center in archeological material is, for Szultka, proof that a Slovincian tribe did not exist. As no Slovincian tribe existed in the medieval period, the Slovincians could not be its remnant in the $19^{\text {th }}$ century. If there is no Slovincian distinctiveness to speak of in the course of history, they are not an ethnic group. And if they are not an ethnic group, they do not exist at all. While I do not deny some logic in Szultka's inference, I suggest some important limitations.

Firstly, Szultka's assumption that identity ("tribality") has its direct effect in the form of settlement duplicates Gustaf Kossinna's long-questioned principle of ethnic method (settlement archaeology), according to which the range of specific archeological culture equals an ethnic community's range, regardless of times. However, archeological data simply does not reflect the ethnic or tribal diversity hypothesis.

Secondly, Szultka thinks in terms of a primordial paradigm, which assumes that identity is an aspect of history: continuity and remote (medieval) "ethnogenesis" is a condition of certain group's existence. Related to this is the conviction that though distinctiveness can fade (like a declining species), formation of a new identity here and now is basically impossible, as it is historically conditioned.

While I understand the reasons behind Szultka's historiocentrism — he is an historiographer, after all - as an anthropologist I cannot ignore the fact that if history is a basis of a group's identity, it does not need to be history wie es eigentlich gewesen ist [Translators note: as it was indeed]: imagined history, called "myth" in anthropology, is enough. What is more, disregarding history in identity formation does not automatically mean lack of distinctiveness or identity. Several examples of groups building their identity in opposition to what we call "history" are known ${ }^{21}$. I will cover the matter of how Slovincians themselves formed their identity later; for now I suggest that while the inexistence of a Slovincian tribe in early medieval times seems likely, we cannot conclude on this basis that the Slovincians did not exist (as an ethnic group) in modern times (again logical reduction), and so we leave open the question of their identity. Let us have a closer look into what Szultka would call the process of making up the Slovincians in modern times.

${ }^{20}$ Ethnic groups and boundaries: the social organization of culture difference / Ed. by F. Barth. Oslo, 1969; cf. Shirokogoroff S.M. Psychomental complex of the Tungus. London, 1935; Obrębski J. Problem grup etnicznych w etnologji i jego socjologiczne ujęcie // Przegląd Socjologiczny. 1936. Vol. 4. P. 177-195.

${ }^{21}$ Cultural Identity and Ethnicity in the Pacific / Ed. by J. Linnekin, L. Poyer. Honolulu, 1990; Carsten J. The Politics of Forgetting: Migration, Kinship and Memory on the Periphery of the Southeast Asian State // Journal of the Royal Anthropological Institute. 1995. Vol. 1. No. 2. P. 317-335; Astuti R. "The Vezo are not a kind of people": identity, difference, and "ethnicity" among a fishing people of western Madagascar // American Ethnologist. 1995. Vol. 22. No 3. P. 464-482; Gow P. "Ex-Cocama": transforming identities in Peruvian Amazonia // Time and memory in indigenous Amazonia: anthropological perspectives / Ed. by C. Fausto, M. J. Heckenberger. Gainesville, 2007. P. 194-215. 


\section{Classification, economy, geography (a Perspective of Tribalisation)}

It is ironic that a useful tool for analysing Slovincian identity is the notion of tribe - this time, however, that of antinaturalist anthropology. The stadial vision of society's development already noted has raised objections by many anthropologists, including Morton H. Fried, who thought that a tribe is not a natural ("primal") being, but a social construct: "most tribes seem to be secondary phenomena in a very specific sense: they may well be the product of processes stimulated by the appearance of relatively highly organized societies amidst other societies which are organized much more simply. (...) tribalism can be viewed as a reaction to the formation of complex political structure rather than a necessary preliminary stage in its evolution" ${ }^{22}$. While the antinaturalist notion of tribe describes mostly effects of the autochthonic world's transformation induced by colonialism ${ }^{23}$, the tribe is "a recurrent and universal residual political phenomenon of both state formation and state expansion, achieving identity and forming boundaries only as a consequence of this external force" 24 .

A tribe is, of course, not only an effect of material influence but also of symbolic impact, in particular the power of classification that a dominant society imposes on its margins, creating groups in theory ${ }^{25}$ or hollow categories ${ }^{26}$. Some American anthropologists realized even in the $20^{\text {th }}$ century that a tribe is “a White man's creation of convenience for talking about Indians, negotiating with them, administering them"27. Let us see how applying this notion of tribe benefits research on the making of (or, in Szultka's words, "making up") Slovincians.

Undoubtedly, the appearance of Slovincians in Hilferding's 1862 elaboration remains closely related to the placement of the Kashubia in three rural districts of the Province of Pomerania: Bytów, Lębork, and above all else Słupsk, about a century earlier ${ }^{28}$. The need

${ }^{22}$ Fried M. H. On the concepts of "tribe" and "tribal society" // Transactions of the New York Academy of Sciences. 1966. Vol. 28. No 4. P. 537. - The development of this thesis: Whitehead N. L. Tribes make states and states make tribes: Warfare and the creation of colonial tribes and states in northeastern South America // War in the tribal zone: Expanding states and indigenous warfare / Ed. by R. B Ferguson, N. L. Whitehead. Santa Fe, New Mexico, 1992. P. 127-150.

${ }^{23}$ Wolf E. R. Europe and the people without history. Berkeley, Los Angeles, 1982.

${ }^{24}$ Whitehead N. L. Tribes... P. 129. - Notion of tribe can refer to pre-colonial period and / or to Europe, what gives a possibility to ignore a discourse of validity of usage of (post)colonial categories to European societies (including those in today's Poland).

${ }^{25}$ Bourdieu P. What makes a social class? On the theoretical and practical existence of groups // Berkeley Journal of Sociology. 1987. Vol. 32. P. 1-17.

${ }^{26}$ Ardener E. Language, ethnicity and population // Journal of the Anthropological Society of Oxford. 1972. Vol. 3. No 3. P. 125-132; Ardener E. Tożsamość i utożsamienie, transl. Z. Mach // Sytuacja mniejszościowa i tożsamość / Ed. by Z. Mach, A. Paluch. Kraków, 1992. P. 21-42.

${ }^{27}$ Kroeber A. L. Nature of the land-holding group // Ethnohistory. 1955. Vol. 2. P. 313.

${ }^{28}$ Wobeser [P. H.] Etwas von dem Wohnsitz der Cassuben in Pommern // Wöchentliche Nachrichten von neuen Landcharten, geographischen, statistischen und historischen Büchern und Sachen. June 7. 1779. Vol. 7. No 23. P. 182-183; Haken [Ch. W.], Probst. Etwas von den Pommerschen Cassuben (...) zu Stolpe in Hinter-Pommern - Beschluß der Nachricht (...) von den Cassuben // Wöchentliche Nachrichten von neuen Landcharten, geographischen, statistischen und historischen Büchern und Sachen. 1779. Vol. 7. No 24. June 14. P. 189-193; 1779. Vol. 7. No 25. June 21. P. 197-204; Brüggeman L. W. Ausführliche Beschreibung des gegenwärtigen Zustandes des Königl. Preußischen Herzogthums Vor- und Hinter-Pommern. Erster Theil welcher außer der allgemeinen Einleitung die Beschreibung des Preußischen Vorpommern enthält. Stettin, 1779; 
to geographically place Kashubia is understandable, due to constant movement of the name "Kashubia" from West to East since it first appeared in written sources in 1238: from Mecklenburg, through Stargard on Ina, to Słupsk, and except of scientific purposes, religious administration played a significant role in this. German clergy concentrated around Anton Friedrich Büsching (not only a known geographer, but also a theologist) were responsible for the localization of Kashubia: the smallest territorial unit was a parish, and the choice of localization was a straightforward consequence of creation in church structure of the circulus vandalicus in 1669-1686, in which the prayers were celebrated in Polish.

This suggests that the Kashubia's localization should not only be understood in geographic, but also in sociological categories. We are not dealing with a description of objective reality here, but with the construction of social reality. An important premise for such statement is the fact that the Kashubia's localization in the late 18th century did not prevent its movement to Eastern Pomerania, where it had been finally located. The fact of "Kashubia" escaping physical localization and objectivization is direct evidence that this name has, or at least had, a subjective and "metaphysical" nature.

Movement of the name "Kashubia" across the map is a geographical testimony of the Kashubians" tribalization. Naming Slavic speaking parishes of the Słupsk district "Kashubia" and parishioners "Kashubians" is an important step in this process, because it irrevocably establishes a Kashubian people (analytically: a tribe) ${ }^{29}$. For these deliberations pastor Haken's partitioning of Kashubians into "mild" (Ger. mild) and "coarse" (Ger. rauh) is a key matter in theory due to "customs and language" and in practice due to resistance against plans of the liquidation of the Polish liturgical language (and replacing it with German). It must be emphasized that, contrary to appearances, we are not dealing with a dichotomy, but with a three-fold classification. First "class" 30 are almost "naturalised" Kashubians, whose customs and language are "the mildest", living in the middle and the south of the Słupsk district. Second "class" are Istker (Haken explains the name with the tendency of using the particle istka), who are of a "coarser" nature, and whose language is very distinct; they live in coastal parishes. Third "class" are Kabatker (the name comes from Kashubian word kabat or kawart, meaning "a coat"), who are supposed to be the "stem" or "core" of Kashubians (Kern-Cassuben), because in parishes bordering the Lębork district, Haken's actions met with the most resistance.

While Hilferding's division of the autochthonic Slavic speaking population of eastern part of the Province of Pomerania differs from Haken's classification in details, both are three-fold. The only significant change is replacing the name "Istker" with Slovincians. So, Hilferding's "discovery" of Slovincians means nothing more than applying this name to a specific class of (Western) Pomeranian Kashubians, who were distinguished almost a century earlier. Showing the way in which "historically defined social interactions, or casual links led to or caused realisation or establishment a specific currently existing being or fact" 31 , suggests that the Slovincians were not a certain natural fact, but a social fact or social construct. Slovincians

Bernoulli J. Reisen durch Brandenburg, Pommern, Preußen, Curland, Rußland und Pohlen, in den Jahren 1777 und 1778. Leipzig, 1779.

${ }^{29}$ Reports made by Büsching's circle are in fact first ethnographic descriptions of Kashubia(ns).

${ }^{30}$ The notion of "class" is purely ethnographic or historiographic in nature here, but at the same time, through Bourdieu it refers to anthropological / sociological meaning.

${ }^{31}$ Hacking I. The social construction of what? Cambridge, 1999. P. 48. 
or, more precisely, ethnographic texts about them, are indeed fictions, just as Szultka would claim, but only 'in the sense that they are 'something made,' 'something fashioned' — the original meaning of fictiō — not that they are false, unfactual, or merely 'as if' thought experiments" ${ }^{\prime 2}$. The question of the Slovincians' genuineness has no greater sense, because its answer reaches outside objective discussion based on a bivalent logic.

Did tribalization have a material aspect in addition to its classification aspect? Definitely. Pastor Haken, giving Kashubia the name of "Western Pomerania's granary"33, clearly suggests the region's economic wealth, understood in terms of economic exploitation, makes Kashubia a zone of development of underdevelopment ${ }^{34}$ or inner colonialism ${ }^{35}$. The source for this interpretation is nothing more than a statement Haken himself made a few sentences earlier: "Kashubian cuisine is very meagre (Ger. geringe)"36, and their costumes, simple and cheap, seem not to be choice but economic need. Kashubian poverty is often mentioned by pastor Lorek, who contemplates its causes in the context of an abundance of food (from being a "granary") and the beauty of the meadows: he concludes that poverty must have not developed until the early $19^{\text {th }}$ century. While Lorek admits that Kashubians "have been overly encumbered in the earlier or later period and even now are being burdened even more in specific places", he found the main reason for their poverty in their own poor management of their resources. In his eyes, this was a fault of "habit" to hire additional help, which not only had to be paid in money, favors, or land, but also needed to be fed and clothed, and this caused the peasants not to gain but to become even poorer. This does not stop him from claiming that such an economic strategy was a need ${ }^{37}$.

The discrepancies in Lorek's explanations should not deflect our attention, but it is important that Kashubia's natural conditions did not support bread grain growth, which was the basis of Prussian agricultural policy in the $18^{\text {th }}$ and $19^{\text {th }}$ centuries $^{38}$. For all these reasons it is hard to see Kashubians as Lorek would suggest, as an original affluent society ${ }^{39}$, and he was partially right when writing of the Kashubians' economic deterioration in the early $19^{\text {th }}$ century,

${ }^{32}$ Geertz $C$. Thick description: Toward an interpretive theory of culture // The interpretation of cultures: Selected essays. New York, 1973. P. 15. — cf.: White H. Metahistory: The historical imagination in nineteenth-century Europe. Baltimore, 1973.

${ }^{33}$ Haken [Ch. W.], Probst. Beschluß der Nachricht (...) von den Cassuben // Wöchentliche Nachrichten von neuen Landcharten, geographischen, statistischen und historischen Büchern und Sachen. June 21. 1779. Vol. 7. No 25. P. 200.

${ }^{34}$ Frank A.G. The development of underdevelopment // Monthly Review. September, 1966. Vol. 18. No 4. P. 17-31.

${ }^{35}$ Hechter M. Internal colonialism: the Celtic fringe in British national development, 15361966. Berkeley, 1975.

${ }^{36}$ Haken [Ch. W.], Probst. Beschluß der Nachricht... P. 200. — In a different variant: "Kashubian nation is very resource efficient": Brüggeman L. W. Ausführliche... P. LXXII.

${ }^{37}$ Lorek G. L. Charakterystyka Kaszubów znad Łeby. Z rysunkami kaszubskich strojów ludowych. Przesądy kaszubskie pod zastanowienie dla przeciwników zalecanego oświecenia ludu i poprawy jego szkół, tłum. M. Darska-Łogin // Niemcy o Kaszubach w XIX wieku. Obraz Kaszubów w pracach G.L. Lorka, W. Seidla i F. Tetznera - Deutsche Berichte über die Kaschuben im 19. Jahrhundert. Das Bild der Kaschuben in den Abhandlungen von G. L. Lorek, W. Seidel und F. Tetzner / Ed. by J. Borzyszkowski. Gdańsk, 2009. P. 69.

${ }^{38}$ Stelmachowska B. Słowińcy i ich kultura. Poznań; Słupsk, 1963. P. 63.

${ }^{39}$ Sahlins M. The original affluent society // Stone age economics. Chicago, 1972. P. 1-39. 
which could be connected with peasant enfranchisement. Take the example of the example of fishermen ${ }^{40}$ who fished by way of lease, wage, or percentage of catch after enfranchisement. Prussian officials used prohibitive lease fees for the right to fish on specific waters, they reduced fish prices, and so on. Fishermen poverty was furthered at the end of $19^{\text {th }}$ century by various state dispositions of fish stocks, protection or bans on fishing methods, and so on ${ }^{41}$.

Economic exploitation and declassation ${ }^{42}$ of Slovincians (and Kashubians in general) is one of the basic manifestations of tribalization. These aspects are not unrelated to how Hilferding combined identity (consciousness, language, and religion) with economy and geographical area, in a way perfectly representing the mechanics of the ecology of ethnicity ${ }^{43}$. Many villages in the Slovincian area were agrarian, but Hilferding mostly saw fishermen from the shores of Lake Łebsko and Lake Gardno as Slovincians. This "professionalization" (and simultaneous gendering) of Slovincian identity led to ethnicization of fishery in literature, which resulted, for example, in (partially) explaining Slovincians' disappearance in the $20^{\text {th }}$ century as due to the decrease in the number of fishermen ${ }^{44}$. While closeness of water in conjunction with an area full of mud, meadows, and arid sands, all so unattractive for agriculture, made the fishery appear to be the base form of the Slovincians' economy, only some Slovincian villages, like Kluki, Gardna or Rowy, had a fishing economy, and this was by no means the result of stricte natural processes ${ }^{45}$. This becomes clear if we examine the history of Kluki, or more precisely of the Otok grange (Ger. Wottock), which oversaw several remote fishing huts, known as Kluki. The main source of subsistence and income was fishing, although cattle husbandry was also practised. In the 1770s a ditch connecting Lake Łebsko and the Baltic Sea was created to drain water from swamps and meadows around Lake $\mathrm{Lebsko}^{46}$. On one side it allowed a German colony of Brenkenhofsthal (Pol. Przybynin) to be established in 1777, while on the other it caused flooding of farms and their destruction. Achieving economic autonomy by Kluki meant that "locals had to search for a source of their subsistence mainly, and periodically only, on Lake Łebsko. Cattle husbandry was could be developed in limited scope again after 100 years, after land amelioration in Kluki" ${ }^{\prime 7}$.

Recognition of fishery as an economy typical for Slovincians seems to be conditioned by environmental determinism in Herder's Kultur. Closeness of water supports seeing fishery as "natural," "primal," or "traditional," and fishing culture as "primitive" or "backward." Speaking in terms of evolutionism: compared to Germans, who already achieved husbandry and tillage, the Slovincians were still "savage." The right to coevalness ${ }^{48}$ is taken from the

${ }^{40}$ Considering the number of benefits that fishing villages had, it was believed that, compared to peasants, fishermen were in a better economic situation in Kashubia. However, the example of Uru Indians from Lake Titicaca in Peru suggests the contrary is also possible (cf.: Wachtel N. Men of the water: the Uru problem (sixteenth and seventeenth centuries) // Anthropological history of Andean polities / Eds. by J. V. Murra, N. Wachtel, J. Revel. Cambridge, 1986. P. 283-310).

${ }^{41}$ Stelmachowska B. Słowińcy... P. 43-51.

${ }^{42}$ I underline the inadequacy of using "underclass" or "(sub)culture of poverty" for Slovincians.

${ }^{43}$ Ethnic groups and boundaries...

${ }^{44}$ Stelmachowska B. Słowińcy... P. 55.

${ }^{45}$ Cf. Hastrup K. Nature as Historical Space // Folk. Journal of the Danish Ethnographic Society. 1989. Vol. 31. P. 5-20.

${ }^{46}$ Bernoulli J. Reisen... P. 142 and following.

${ }^{47}$ Szultka Z. Studia... P. 84.

${ }^{48}$ Fabian J. Time and the Other: how anthropology makes its object. New York, 1983. 
Slovincians, despite fishery not being a Stone Age economy but a specialized adaptation to the complex natural environment, which can be exploited in different ways. It was not until legal regulations were introduced to limit the amount of fight caught that fishery was seen as a specific type of economy, which happened no later than in 1794, but most likely no earlier than the late $16^{\text {th }}$ century ${ }^{49}$. This means that fishery most likely was not an "ethnic" marker earlier. Simultaneously, we should not assume that the Slovincians' ancestors were fishers in the area; it should rather be taken for granted that the population of fishers was demographically dynamic, to which I return later ${ }^{50}$.

Since Hilferding's times, Slovincians have been placed between two lakes: Lake Gardno to the west and Lake Lebsko to the east, separated from the Baltic Sea to the north only by narrow spits with a strip of moving dunes. Rowokół Hill towers over the entire area. As a result of amelioration, the lower lying grounds are currently dry, but in the $19^{\text {th }}$ century the landscape was composed of swamps and alluvial meadows occupying the space between larger forest complexes. This area appeared to scholars as "a peculiar reserve and a refugium" 51 , yet the Slovincians' geographic isolation was not total. Difficulties reported by scholars faring through this area concerned only the south-western part of Slovincian land, which was full of marshes - mainly for reasons already mentioned, the Kluki area that constituted a border between the Slovincians and Pomerania's Kashubians, according to Hilferding. From the south-east, access to Slovincian land was easy, and we know of its connections with the rest of the district by several historical sources and even the same scholars who highlighted this area's isolation.

Geographic isolation was seen as the main cause for prolonged resistance against Germanization and the basis for the creation of a "language island" in the late $19^{\text {th }}$ century in the sea of Germanism (to continue the metaphor). Not being fooled by geographic determinism, I claim that we should not reach into nature for explanations of social phenomena, but rather we should look to culture or the social domain. And so, Slovincians are a group that seemed to wish to avoid the outside world's influences, and was marginalized by the outside world at the same time. In the naturalist paradigm, such peoples are called "refugial," but it is more valid to call them a specific type of tribe created as an indirect consequence of the state's presence and that avoided contact with national society until the $19^{\text {th }}$ century, to paraphrase Whitehead ${ }^{52}$.

This, the Slovincians are neither an effect of "natural" historical processes of "surviving" in hardly accessible geographic conditions, nor are they a simple consequence of intellectual elites "making up" a name in the $18^{\text {th }}$ century. The creation of Slovincians began much earlier, as an aspect of the Kashubians' tribalization, which is just a step in a prolonged process of the Slavic world's creation by the Germanic world ${ }^{53}$, which is itself a creation of Rome ${ }^{54}$. There

${ }^{49}$ Stelmachowska B. Słowińcy... P. 43.

${ }^{50}$ Ethnic groups and boundaries...; Ardener E. Language...; Ardener E. Tożsamość...

${ }^{51}$ Stelmachowska B. Słowińcy... P. 16.

${ }^{52}$ Whitehead N. L. Tribes... P. 134.

${ }^{53}$ Of course, it was not only the Germanic world that played its part in the Slavs' tribalization. Other important subjects were Byzantium, Avars, and the Islamic world (cf.: Curta F. The making of the Slavs: History and archaeology of the lower Danube region c. 500-700.Cambridge, 2001; Adamczyk D. Od dirhemów do fenigów: Reorientacja bałtyckiego systemu handlowego na przełomie X i XI wieku // Średniowiecze Polskie i Powszechne. 2007. Vol. 4. P. 15-27.

${ }^{54}$ Geary P. J. Before France and Germany: the creation and transformation of the Merovingian world. New York, 1988. P. vi. 
is no need to discuss the Kashubian's tribalization in a more detailed way. It is enough to say that, while Germanization in a stricte political way as official (proto)nationalism (guild rights, language imperialism, reformation, and so on) has enormous meaning, a cultural aspect of Germanization is of at least equal importance - as a much earlier process of fairly consensual assimilation proceeding alongside a demographic process of Ostsiedlung. Pomerania's Germanization did not occur through bloody conquests, as it did in Mecklenburg or Prussia, where Germanization and colonization were connected by (cultural) genocide, but in a rather peaceful manner, mainly through feudalism, church, and urbanization ${ }^{55}$. This difference is noteworthy because it is directly related to the Kashubians', and in particular the Slovincians', cultural strategies, who against common belief did not resist Germanization openly, but, as a peaceful society, resorted to flight, defection, desertion, and complaints ${ }^{56}$, which are classical weapons of the weak ${ }^{57}$. Kashubian and Slovincian culture should be seen as an expression of adaptation to conditions of political marginalization, economic exploitation, and powerlessness. It is a time to go outside the analysis of "objective" conditions constituting a certain social system and, in search of an answer to a question not of fact but of the ways Slovincians existed in the world, to look at the problem from the perspective of the subject under discussion.

\section{Culture ("The NaTIVE's POINT OF VIEW")}

Riots against the removal of sermons in Slavic, which occurred in some villages in Kashubia from the $18^{\text {th }}$ to the mid- $19^{\text {th }}$ centuries, are a mythopoetic foundation of the belief in Kashubians' and, of course, Slovincians' active resistance. I assume that the importance of these events is exaggerated by Polish researchers, who are either misguided by German pastors' reports written from the victim's perspective, or are wishful thinking and fail to see the importance of some facts: they were relatively short-lived, they occurred only in parish seats, and such aggression was symbolic in nature (vituperation, spitting, collective stone throwing), with significant participation of women, proving that these riots were of a religious and not an ethnic nature.

The practice of remaining silent: a more or less direct refusal of dialog, not answering questions to suggest lack of knowledge of the language they were asked in, as well as concealing information, is in a strict strategy to avoid violence. In my own research I noticed such strategies at work: I confronted the refusal of contact during my fieldwork, and I was aware that a certain journalist ${ }^{58}$ met with a similar refusal in 1990 s, and that Slovincians concealed knowledge of Slavic languages from Polish researchers. However, the discovery that pastor Haken already informed that a "majority [of Kashubians] understands German

\footnotetext{
${ }_{55}^{5}$ Ślaski K. Dzieje ziemi kołobrzeskiej do czasów jej germanizacji. Toruń, 1948. P. 81.

${ }^{56}$ Źródła do kaszubsko-polskich aspektów dziejów Pomorza Zachodniego do roku 1945 / Ed. by B. Wachowiak. Book I: Pomorze Zachodnie pod rządami książąt plemiennych i władców z dynastii Gryfitów (990-1121-1637-1648/1653); Book II: Pomorze Zachodnie w państwie brandenbursko-pruskim (1653-1815) / Ed. by Z. Szultka. Poznań; Gdańsk, 2006.

${ }^{57}$ Scott J.C. Weapons of the weak: everyday forms of peasant resistance. New Haven, 1985.

${ }^{58}$ Bolduan T. Losy społeczne i polityczne Słowińców w Klukach w latach 1945-1975. Próba oceny // Studia kaszubsko-słowińskie. Materiały z II Konferencji Słowińskiej (Łeba 11-13.05.1992) / Ed. by J. Treder. Łeba, 1992. P. 9-30.
} 
decently but has no will to answer a German in German language" ${ }^{59}$ led me to conclude that those acts of remaining silent are not random, short-lived, or only directed against Poles, but constitute a long-lasting (230 years) scheme of social behavior towards outsiders, regardless of their ethnic identity. From this point of view, it seems obvious that the practice of complaining (verbally and in writing), also authenticated in the post-war period, is a structural inversion of silence.

For the past two paragraphs I have written about symbolic ways of keeping social distance, but it is impossible not to note that escapes, defections, or desertions mentioned previously are a form of keeping said distance, but in a geographical manner. It thus should not be surprising that in the times of the Polish People's Republic, Slovincian departures to Germany without an obligatory permit were not uncommon, despite increased state control of movement.

At first, Slovincians seem to be a type of society that is closed off to outsiders, an anthropoemic society, so a one that "vomits" outsiders (as opposed to anthropophagic societies, which "absorb" them $)^{60}$, but a closer look at the kinship forces us to abandon this perspective as over simplistic. What is important is not as much a consanguinity (blood ties with specification of origin), which was an ideological basis for the naturalist notion of tribe, as is affinity, which, since Lévi-Strauss's revolutionary work ${ }^{61}$, is assumed to play a key role in the process of reproducing the community. Slovincians, from the very beginning, were presented as an endogamic society, despite the fact that marriages with foreign settlers (mainly Germans) had occurred at least since late $18^{\text {th }}$ century ${ }^{62}$. These occurrences of exogamy force us to look at reproducing community not in terms of the rate of natural increase ${ }^{63}$, but in terms of familiarizing (chosen) outsiders. Materials from the post-war period prove that the marriage itself is not equal to assimilation or integration, and does not necessarily provide a feeling of safety in the family ${ }^{64}$. Thus, we cannot exclude the fact that earlier, when the scope of mixed marriages was much smaller, affinity was final evidence of identity. The process of assimilation occurred mostly through working together. Fishery, and on a larger scale annual seine-haul fishing in the winter or peat digging in the spring (the so-called Black Wedding), not only provided resources needed for survival, but also (re)produced social bonds, marking symbolic boundaries of the community. It is worth mentioning that in process of mass emigration from Kluki, kin provided not only a support, but also a reason (or excuse) to leave.

All signs are that in Slovincian villages, an analogous mechanism of cultural reproduction was present (with varying intensity), alhtough this structural similarity of relatively autonomic local communities does not find expression in ethnic identity, which is based on a conviction about a common origin (history ${ }^{65}$. It is impossible to deny that in the Prussian/German social system, Slovincians as a whole constituted "the homogenizing effect of homogeneous

${ }_{59}$ Pomorze Zachodnie pod...P. 255; Haken [Ch. W.] Beschluß ... P. 200.

${ }^{60}$ Lévi-Strauss C. Tristes Tropiques. New York, 1961. P. 386.

${ }^{61}$ Lévi-Strauss C. The Elementary Structures of Kinship. Boston, 1969.

${ }^{62}$ Szultka Z. Studia... 89-90; Czarnik A. Gardna Wielka. Słupsk, 2001; URL: http://www. lebakaschuben.de.

${ }^{63}$ Analogically: Nowak O., Liczbińska G., Piontek J. Opportunity for the Operation of Natural Selection in a Contemporary Local Population (The Case of Slovincians, Poland) // Advances in Anthropology. 2013. Vol. 3. No. 3. P. 121-126; cf.: Ethnic groups and boundaries...; Ardener E. Language...

${ }^{64}$ Rybicki H. 1) Nazywano ich Słowińcami. Słupsk, 1995; 2) Nazywano ich Słowińcami. Część druga: wybór źródeł. Gdańsk; Wejherowo, 2003.

${ }^{65}$ History and Ethnicity / Ed. by E. Tonkin, M. K. Chapman, M. McDonald. Routledge, 1989. 
conditionings," and each of them had a "sense of one's place" ${ }^{\circ 6}$, although homogeneous individual experiences never were transformed into group consciousness, and so a transition from theoretical group (or hollow category) to practical group did not occur. This is why Slovincians did not constitute an autonomous ethnic group or a part of any other ethnic group. Despite administrators and intellectuals of one or another origin imagined Slovincians to be a community, such an imagination was alien to themselves. While I agree with Szultka, that naming such an imagination as an ethnicity is an abuse ${ }^{67}$, I reject the conclusion from this of the inexistence of Slovincians and including them in the Kashubian ethnic group (an implicit ethnographic group status), if only because Kashubians did not develop a single ethnic identity that the Slovincians would need to see as their own. Findings so far prove that Slovincians undisputedly existed as a cultural, but ethnic indifferent, group ${ }^{68}$.

Transformation of Slovincian consciousness and ethnicization of their identity happened as a result of centuries-long assimilation as late as the early $20^{\text {th }}$ century, when the memory of a Slavic past was replaced with sense of German nationality (ethnicity), and German became the basic tool of communication in the home as well as in public. While both German and Slavic speaking scholars claim that Germanization was strongly opposed, I cannot ignore the premises that a wish for Slovincians to become German was not unilateral - it was not only top-down mimicry ${ }^{69}$, but also bottom-up mimesis ${ }^{70}$. Of course, this is not far-reaching change, just a simulation and a game of appearances. Changes applied to language and formal (ethnic) self-identification, thus as a structural level, and did not interfere with the symbolic level, where boundaries of local community were held in the same way as before, as already mentioned.

Dialectical processes of change and persistence are easiest to follow in a sphere of language. Initially, the lack of knowledge of Kashubian was only simulated, mostly in public, where German was used in place of Kashubian out of shame or fear (and this included attempts to change surnames to German), but over time this process also affected what happened in homes. Germanization of Slovincian lexis, morphology, and so on took place at the same time. This language shift was seen as "a language extinction" and "a disappearance / a loss of identity," but from an anthropological view Germanization does not mean a gap in continuity of Slovincian identity and cultural strategies, because "the transformation of a culture is a mode of its

\footnotetext{
${ }^{66}$ Bourdieu P. What makes a social class? P. 5, 6.

${ }^{67}$ Proving Slovincians' (and Kashubians') ethnicity would be however possible due to «standardization of interaction» (Ethnic groups and boundaries... P. 18) with Germans, and later Poles, what is demonstrated in my article, nevertheless, firstly, the researchers verified Slovincians' ethnicity outside of this theory and, secondly, situationism (ahistoricity) is clearly a weakness of Barth's idea. ${ }^{68}$ Lozoviuk P. The problems of the issue of «ethnic indifference» in the Czech language milieu // Ethnic studies and the urbanized space in social anthropological reflections / Ed. by Z. Uherek. Praha, 1998. P. 41-47. - From other perspective it can be said that Slovincians are not affected by Eurocentric notions of ethnicity (Frank E. H. Etnicidad: contribuciones etnohistóricas a un concepto difícil // Etnohistoria del Amazonas / Ed. by P. Jorna, L. Malaver, M. Oostra. Quito, 1991. P. 63-81) and group (Wagner R. Are there social groups in the New Guinea Highlands? // Frontiers of anthropology / Ed. by M. J. Leaf. New York, 1974. P. 95-122).

${ }^{69}$ Bhabha H. Of Mimicry and Man: The Ambivalence of Colonial Discourse // October. 1984. Vol. 28. P. 125-133.

${ }^{70}$ Taussig M. T. Mimesis and alterity: a particular history of the senses. New York, 1993.
} 
reproduction" "71. Just as Germans were assimilated, German words, grammar rules, etc. were familiarized through their integration into the local language system. What in a philological view is Germanization (differentiation), in an anthropological view is Slovincization (homogenization). Despite Slovincians' use of German as their Muttersprache, linguistic union with Germany was not equal to removing the community's symbolic boundaries, because "people can turn these alien structural influences to the service of their indigenous symbolic systems and thereby symbolically reinforce their customary boundaries" 72 . Further, after World War II, a structural inversion of that correlation occurred, where the presence of trails of Kashubian in the language "objectively" testified to a Slavic past and Slavic identity of autochthons living between lakes Gardno and Łebsko, regardless of what autochthons or colonists thought of it themselves ${ }^{73}$.

As far as memory is concerned, most Slovincians claimed that they are and have always been German. Even if some of them are aware of some relation with Kashubians, using that name to tell about their grandmother or $18^{\text {th }}$ century Kluki residents, they do not see it as any basis to relate themselves to Kashubians. This category was only used to speak of the past, which is widely known to be "a foreign country" 74 . Slovincians do not identify in terms of history that happened, but historicity ${ }^{75}$ or oblivion, which is expressed in an imagination of German village of Kluki that makes two types of forgetting easy to observe: that constitutive in the formation of a new identity, and a structural amnesia (of kinship) ${ }^{76}$. In a limitation of Slavic lexis, morphology, etc., a next type of forgetting is seen, planned obsolescence ${ }^{77}$, and in traumatic relation with Soviet soldiers and Polish colonists (especially for women), it is a humiliated silence ${ }^{78}$ that seems to remain in a certain relation with social distancing.

\section{Closure}

While it is commonly recognised today that there is a discontinuity of credibility between Slovincians and Kashubians, I have shown that there is little difference between them in terms of their existence in social space and even less in terms of their social genesis, i.e. mechanisms of their formation (creation). Slovincians and Kashubians as social constructs have analogous ontological status, and they are equally real due to the very fact of their social existence. Despite there being no "genealogical" continuity among them that would have developed in an event of natural evolution, there is an "epistemological" continuity of subsequent and consequent steps of a perpetual process of making the Other in social space.

Slovincians' longue durée history happened slowly, without any major changes, until the early $20^{\text {th }}$ century. The language shift, observed quite thoroughly during the second half of the $19^{\text {th }}$ century and the first decades of the following century, was basically not much of a change.

${ }^{71}$ Sahlins M. D. Islands of History. Chicago; London, 1985. P. 138.

${ }^{72}$ Cohen A. P. The symbolic construction of community. London; New York, 1985. P. 75.

${ }^{73} \mathrm{~Np}$.: Hinze F. Slovinzische Fischzugnamen von Garder See in Hinterpommern. Nachleben und Etymologie slovinzische Namen // Zeitschrift für Slawistik. 1970. Book 15. No. 3. P. 386-392.

${ }^{74}$ Lowenthal D. The Past is a Foreign Country. Cambridge, 1985.

${ }^{75}$ Hirsch E., Stewart C. Introduction: ethnographies of historicity // History and Anthropology. 2005. Vol. 16. No. 3. P. 261-274.

${ }^{76}$ Connerton P. Seven types of forgetting //Memory Studies. 2008. Vol. 1. P. 62-64.

${ }_{77}$ Connerton P. Seven types... P. 66-67.

${ }^{78}$ Connerton P. Seven types.... P. 67-69. 
What is more, Germanization of (ex-)Slovincians caused them to be "invisible" against the background of German society, and they seemed not much different culturally from Germans. The past, rather than present, testified to (ex-)Slovincians' distinctiveness, with locality and autochthony as its final sign.

A radical change happened in early post-war years, when the cultural, social, and political environment changed quickly and diametrically. In their lifespan, an individual was stigmatized in their youth as an Other by German society because of being Slavic; in their old age the same individual was stigmatized as an Other by Polish society (and Soviet soldiers) because of his/her Germanness. As a result of territorial changes, (ex-)Slovincians, who successfully simulated German identity before the war, became "outsiders" in the Polish social environment. Thus, we are facing a reproduction of Slovincian status as Others in terms of structural inversion.

Both an imagination of (ex-)Slovincians being confined to and by their territory and real attempts of "incarcerating" them in one place ${ }^{79}$ had the same effect of mass exodus from Kluki, which scholars saw as an act of destruction of the last diacritic of the group's distinctiveness, and thus its "death." If Germanization often provided a reason to speak of losing Slovincian identity and Slovincian culture, then emigration, in terms of displacement and uprooting, was key evidence. For this reason, Slovincians' historiography basically ends in the 1970s, metaphorically speaking, at the moment the last people from Kluki took their seats on the trains. Professional scholars have no real interest in "afterlife" of (ex-)Slovincians, and so this aspect was important only to journalists ${ }^{80}$ and employees of the Museum of the Slovincian Village in Kluki. My attempts to obtain a grant for field research amongst Kluki emigrants, and thus attempts to persuade the project's reviewers that uprooting does not mean an end for a group, culture, or identity, against a stubborn conviction of cultural-geographic demise of (ex-)Slovincians, ended up a failure, alas.

When, against the odds, I tried contacting former Kluki residents in Hamburg, I met with refusal, as I noted earlier. An awareness of assignment to a particular class defined by its history, alone caused the would be group under investigation to resist stigmatization and reproduction of an Other's status, resulting in shutting out social relations with an anthropologist. Although my fieldwork did not result in direct success, it led to finding sources and connecting all patterns and proofs confirming the existence of certain processes and patterns of actions, shedding new light on a problem of Slovincian identity.

Информация о статье:

Автор: Филип, Мариуш — PhD, университет Адама Мицкевича, Познань, Польша, mfilip@amu.edu.pl; OrcID https://orcid.org/0000-0002-1992-0929

Название: A tribe after all? The problem of Slovincians' identity in an anthropological approach [И все-таки племя? Антропологический подход к проблеме идентичности словинцев]

Резюме: Вопрос о (не)существовании словинцев был одним из наиболее интригующих в славистических исследованиях. Словинцы первоначально были обнаружены и определены как “этническая группа" (Гильфердинг, 1862), спустя 130 лет их существование было опровергнуто и объявлено «выдумкой» (Szultka, 1992). Усвоив уроки “эпистемологического поворота”, который предполагает смещение акцента с "есть ли" на "как” что-либо существует, автор критически рассматривает обоснования и значение аргументов о том, что никогда не было никакой “этнической группы” словинцев, поскольку в раннее средневековье такого племени не было. В первой части статьи показывается, что

${ }^{79}$ Appadurai A. Putting hierarchy in its place// Cultural Anthropology. 1988. Vol. 3. No. 1. P. 36-49.

${ }^{80}$ Bolduan T. Losy społeczne... 
категоричное утверждение Szultka подтверждается очень ограниченными доказательствами, вытекающими из концептуально ограниченного («археологического», «натуралистского») понятия племени. Во второй части, ознакомив читателя с антинатуралистским антропологическим понятием племен как «вторичных явлений», автор стремится показать, что в ходе истории словинцы постоянно трайбализировались, обосабливались на материальном и символическом уровне немцами и поляками (и некоторыми другими субъектами славянской идентичности). Даже если быть племенем не означает быть этнической группой, словинцы могут быть фикцией только с точки зрения социального конструирования.

Ключевые слова: словинцы, кашубы, племя, идентичность

Литература, использованная в статье:

Adamczyk, Dariusz. Od dirhemów do fenigów: Reorientacja bałtyckiego systemu handlowego na przełomie $\mathrm{X}$ i XI wieku [From dirhem to fenig. Reorientation of the Baltic system of trade at the turn of $10^{\text {th }}$ and $11^{\text {th }}$ century] // Średniowiecze Polskie i Powszechne. 2007. Vol. 4. Pp. 15-27.

Anton, Karl Gottlob. Erste Linien eines Versuches über die alten Slawen Ursprung, Sitten, Gebräuche, Meinungen und Kenntnisse. Leipzig: Adam Friedrich Böhme, 1783. 178 p.

Appadurai, Arjun. Putting hierarchy in its place// Cultural Anthropology. 1988. Vol. 3. No. 1. Pp. 36-49.

Ardener, Edwin. Language, Ethnicity and Population // Journal of the Anthropological Society of Oxford. 1972. Vol. 3. No. 3. Pp. 125-132.

Ardener, Edwin. Tożsamość i utożsamienie [Identity and Identification], in Mach, Zdzisław; Paluch, Andrzej K. (eds). Sytuacja mniejszościowa i tożsamość. Krakow: Wydawnictwo Uniwersytetu Jagiellońskiego, 1992. Pp. 21-42.

Astuti, Rita. «The Vezo Are Not a Kind of People»: Identity, Difference, and Ethnicity among a Fishing People of Western Madagascar // American Ethnologist. 1995. Vol. 22. No. 3. Pp. 464-482.

Barth, Fredrik (ed.). Ethnic Groups and Boundaries: The Social Organization of Culture Difference. Bergen; Oslo: Universitetsforlaget; London: George Allen and Unwin, 1969. 153 p.

Bernoulli, Johann. Reisen durch Brandenburg, Pommern, Preußen, Curland, Rußland und Pohlen, in den Jahren 1777 und 1778. Leipzig: Caspar Fritsch Publ., 1779. 298 p.

Bhabha, Homi. Of Mimicry and Man: The Ambivalence of Colonial Discourse // October. 1984. Vol. 28. Pp. 125-133.

Bolduan, Tadeusz. Losy społeczne i polityczne Słowińców w Klukach w latach 1945-1975. Próba oceny // Treder, Jerzy (ed.). Studia kaszubsko-słowińskie. Materiały z II Konferencji Słowińskiej (Łeba 11-13.05.1992). Leba: Zrzeszenie Kaszubsko-Pomorskie, 1992. Pp. 9-30.

Bourdieu, Pierre. What makes a social class? On the theoretical and practical existence of groups, in Berkeley Journal of Sociology. 1987. Vol. 32. Pp. 1-17.

Brüggeman, Ludewig Wilhelm. Ausführliche Beschreibung des gegenwärtigen Zustandes des Königl. Preußischen Herzogthums Vor- und Hinter-Pommern. Erster Theil welcher außer der allgemeinen Einleitung die Beschreibung des Preußischen Vorpommern enthält. Stettin: H. G. Effenbart Publ., 1779. 276 p.

Buko, Andrzej. The Archaeology of Early Medieval Poland: Discoveries — Hypotheses — Interpretations. Leiden; Boston: Brill, 2008. 475 p.

Carsten, Janet. The Politics of Forgetting: Migration, Kinship and Memory on the Periphery of the Southeast Asian State, in Journal of the Royal Anthropological Institute. 1995. Vol. 1. No. 2. Pp. 317-335.

Cassirer, Ernst. An Essay on Man: An Introduction to a Philosophy of Human Culture. New York: Doubleday Anchor Books, 1944. 294 p.

Cohen, Anthony P. The symbolic construction of community. London; New York: Routledge, 1985.128 p. Connerton, Paul. Seven Types of Forgetting // Memory Studies. 2008. Vol. 1. No. 1. Pp. 59-71.

Curta, Florin. The Making of the Slavs: History and Archaeology of the Lower Danube Region c. 500-700. Cambridge: Cambridge University Press, 2001. 463 p.

Czarnik, Andrzej. Gardna Wielka. Słupsk: Pomorska Akademia Pedagogiczna, 2001. 202 p.

Fabian, Johannes. Time and the Other: How Anthropology Makes its Object. New York: Columbia University Press, 1983. 205 p.

Filip, Mariusz. Od Kaszubów do Niemców. Tożsamość Słowińców z perspektywy antropologii historii. Poznan: Wydawnictwo Nauka i Innowacje Publ., 2012. 237 p.

Frank, Andre Gunder. The Development of Underdevelopment // Monthly Review. September, 1966. Vol. 18. No. 4. Pp. 17-31. 
Frank, Erwin H. Etnicidad: contribuciones etnohistóricas a un concepto difícil // Jorna, Peter; Malaver, Leonor; Oostra, Menno (eds). Etnohistoria del Amazonas. Quito: Abya-Yala, 1991. Pp. 63-81.

Fried, Morton H. On the Concepts of «Tribe» and «Tribal Society» // Transactions of the New York Academy of Sciences. 1966. Vol. 28. No. 4. Pp. 527-540.

Geary, Patrick J. Before France and Germany: The Creation and Transformation of the Merovingian World. New York: Oxford University Press, 1988. 259 p.

Geertz, Clifford. Thick Description: Toward an Interpretive Theory of Culture, in The Interpretation of Cultures: Selected Essays. New York: Basic Books, 1973. Pp. 3-30.

Gow, Peter. «Ex-Cocama»: Transforming Identities in Peruvian Amazonia // Fausto, Carlos; Heckenberger, Michael (eds). Time and Memory in Indigenous Amazonia: Anthropological Perspectives. Gainesville: University Press of Florida, 2007. Pp. 194-215.

Hacking, Ian. The Social Construction of What? Cambridge: Harvard University Press, 1999. 261 p.

Haken, [Christian Wilhelm]. Etwas von den Pommerschen Cassuben (...) zu Stolpe in Hinter-Pommern [Somewhat about the Pomeranian Kashubians (...) by Słupsk in Farther Pomerania], in Wöchentliche Nachrichten von neuen Landcharten, geographischen, statistischen und historischen Büchern und Sachen. 1779. Vol. 7. No. 24. June 14. Pp. 189-193 (in German).

Haken, [Christian Wilhelm]. Beschluß der Nachricht (...) von den Cassuben [Resolution of the Message (...) about Kashubians], in Wöchentliche Nachrichten von neuen Landcharten, geographischen, statistischen und historischen Büchern und Sachen. 1779. Vol. 7. No. 25. June 21. Pp. 197-204 (in German).

Hastrup, Kirsten. Nature as Historical Space // Folk. Journal of the Danish Ethnographic Society. 1989. Vol. 31. Pp. 5-20.

Hechter, Michael. Internal Colonialism: The Celtic Fringe in British National Development, 1536-1966. Berkeley: University of California Press, $1975.361 \mathrm{p}$.

Herder, Johann Gottfried. J. G. Herder on Social and Political Culture. Ed. by Barnard, Frederick M. London: Cambridge University Press, 1969. 329 p.

Hilferding, Aleksander. Ostatki Słowian na południowym brzegu Bałtyckiego Morza // Kolberg, Oskar (ed.). Pomorze. Krakow: Polskie Wydawnictwo Muzyczne; Warszawa: Ludowa Spółdzielnia Wydawnicza, 1965. Pp. 311-452.

Hinze, Friedhelm. Slovinzische Fischzugnamen von Garder See in Hinterpommern. Nachleben und Etymologie slovinzische Namen // Zeitschrift für Slawistik. 1970. Vol. 15. No. 3. Pp. 386-392.

Hirsch, Eric; Stewart, Charles. Introduction: Ethnographies of Historicity // History and Anthropology. 2005. Vol. 16. No. 3. Pp. 261-274.

Knoop, Otto. Etwas von den Kaschuben // Unsere Heimat. Beilage zur Kösliner Zeitung. 1925. No. 1 (January 31), no. 2 (February 21), no. 4 (March 28), no. 6 (April 27).

Koblischke, Julius. Der Name «Slovinzen»// Mitteilungen des Vereins für Kaschubische Volkskunde. 1908. Vol. 1. No. 1. Pp. 12-14.

Kroeber, Alfred L. Nature of the land-holding group, in Ethnohistory. 1955. Vol. 2. Pp. 303-314.

Krofey, Szyman. Duchowne piesnie D. Marcina Luthera y ynßich naboznich męzow. Zniemieckiego w Slawięsky ięzik wilozone. Gdańsk, 1586. 158 p.

Lévi-Strauss, Claude. The Elementary Structures of Kinship. Boston: Beacon Press, 1969. 541 p.

Lévi-Strauss, Claude. Tristes tropiques. New York: Criterion Books Publ., 1961. 404 p.

Linnekin, Jocelyn; Poyer, Lin (eds). Cultural Identity and Ethnicity in the Pacific. Honolulu: University of Hawaii Press, 1990. 323 p.

Lorek, Gottlieb Leberecht. Charakterystyka Kaszubów znad Łeby. Z rysunkami kaszubskich strojów ludowych / Zur Charakteristik der Kassuben am Leba-Strome. Mit einer Abbildung kassubischer Volkstrachten // Borzyszkowski, Józef (ed.). Niemcy o Kaszubach w XIX wieku. Obraz Kaszubów w pracach G. L. Lorka, W. Seidla i F. Tetznera / Deutsche Berichte über die Kaschuben im 19. Jahrhundert. Das Bild der Kaschuben in den Abhandlungen von G. L. Lorek, W. Seidel und F. Tetzner. Gdańsk: Instytut Kaszubski Press, 2009. Pp. 37-78, 83-126.

Lorentz, Friedrich. Nochmals der Name «Slovinzen»// Mitteilungen des Vereins für kaschubische Volkskunde. 1908. Vol. 1. No. 1. Pp. 14-16.

Lowenthal, David. The Past is a Foreign Country. Cambridge: Cambridge University Press, 1985. 489 p. Lozoviuk, Petr. The Problems of the Issue of «Ethnic Indifference» in the Czech Language Milieu // Uherek, Zdeněk (ed.). Ethnic studies and the urbanized space in social anthropological reflections. Praha: Institute of Ethnology of the Academy of Sciences of the Czech Republic Press, 1998. Pp. 41-47. 
Morgan, Lewis H. Ancient Society. Or Researches in the Lines of Human Progress from Savagery through Barbarism to Civilization. Chicago: C. H. Kerr Publ., 1877. 570 p.

Nowak, Oskar; Liczbińska, Grażyna; Piontek, Janusz. Opportunity for the Operation of Natural Selection in a Contemporary Local Population (The Case of Slovincians, Poland) // Advances in Anthropology. 2013. Vol. 3. No. 3. Pp. 121-126.

Obrębski, Józef. Problem grup etnicznych w etnologji i jego socjologiczne // Przegląd Socjologiczny. 1936. Vol. 4. Pp. 177-195.

Pontanus [=Brüggeman(n), Michael]. Parvus Catechismus D. Martini Lvtheri Germanica - Vandalicus $=$ Der kleine Catechißmus D. Martini Lutheri / Deutsch vnnd Wendisch gegen einander gesetzt. Mit anhange der Sieben Bußpsalmen König DAVIDS = Mały Catechism D Marciná Lutherá Niemiecko Wándalski ábo Słowięski. Gdansk: Jerzy Rhet., 1643. 68 p.

Rybicki, Hieronim. Nazywano ich Słowińcami. Slupsk: Wyższa Szkoła Pedagogiczna, 1995. 278 p.

Rybicki, Hieronim. Nazywano ich Słowińcami. Cz. 2. Wybór źródeł. Gdansk: Instytut Kaszubski; Wejherowo: Muzeum Piśmiennictwa i Muzyki Kaszubsko-Pomorskiej, 2003. 262 p.

Sahlins, Marshall D. Islands of History. Chicago; London: The University of Chicago Press, 1985. 180 p.

Sahlins, Marshall D. The Original Affluent Society, in Stone Age Economics. Chicago: Aldine-Atherton Publ., 1972. Pp. 1-39.

Sahlins, Marshall D.; Service, Elman R. (eds). Evolution and Culture. Ann Arbor: University of Michigan Press, 1960. $131 \mathrm{p}$.

Scott, James $C$. Weapons of the Weak: Everyday Forms of Peasant Resistance. New Haven; London: Yale University Press, 1985. 389 p.

Shirokogoroff, Sergei Mikhailovich. Psychomental complex of the Tungus. London: Kegan Paul Publ., 1935. $469 \mathrm{p}$.

Ślaski, Kazimierz. Dzieje ziemi kołobrzeskiej do czasów jej germanizacji. Torun: Towarzystwo Naukowe Publ., 1948. 116 p.

Stelmachowska, Bożena. Słowińcy i ich kultura. Poznan: Wydawnictwo Poznańskie Publ.; Slupsk: Polskie Towarzystwo Historyczne Publ., 1963. 153 p.

Szultka, Zygmunt. Studia nad rodowodem i językiem Kaszubów. Gdansk: Muzeum Piśmiennictwa i Muzyki Kaszubsko-Pomorskiej w Wejherowie, 1992. 187 p.

Taussig, Michael. Mimesis and Alterity: A Particular History of the Senses. New York: Routledge, 1993. 299 p. Tonkin, Elizabeth; McDonald, Maryon; Chapman, Malcolm (eds). History and Ethnicity. London: Routledge, 1989. $240 \mathrm{p}$.

Treder, Jerzy. Komu może przeszkadzać etnonim Słowińcy? // Czarnik, Andrzej (ed.). Obrazy Ziemi Słupskiej. Społeczeństwo — administracja — kultura. Materiały z VII Konferencji Kaszubsko-Pomorskiej, Słupsk 5-6 grudnia 2002. Slupsk: Starostwo Powiatowe Publ., 2003. Pp. 59-70.

Wachowiak, Bogdan (ed.). Źródła do kaszubsko-polskich aspektów dziejów Pomorza Zachodniego do roku 1945. Vol. I: Pomorze Zachodnie pod rządami książąt plemiennych i władców z dynastii Gryfitów (990-1121-1637-1648/1653); Vol. II: Pomorze Zachodnie w państwie brandenbursko-pruskim (1653-1815). Szultka, Zygmunt; Poznan: Wydawnictwo Poznańskie; Gdansk: Zrzeszenie Kaszubsko-Pomorskie, 2006. 745 p.; 580 p.

Wachtel, Nathan. Men of the Water: The Uru Problem (Sixteenth and Seventeenth Centuries) // Murra, John V.; Wachtel, Nathan; Revel, Jacques (eds). Anthropological History of Andean Polities. Cambridge: Cambridge University Press, 1986. Pp. 283-310.

Wagner, Roy. Are there Social Groups in the New Guinea Highlands? // Leaf, Murray J. (ed.). Frontiers of Anthropology: An Introduction to Anthropological Thinking. New York: D. Van Nostrand Company Publ., 1974. Pp. 95-122.

White, Hayden. Metahistory: The Historical Imagination in Nineteenth-Century Europe. Baltimore: Johns Hopkins University Press, 1973. 448 p.

Whitehead, Neil L. Tribes Make States and States Make Tribes: Warfare and the Creation of Colonial Tribes and States in Northeastern South America // Ferguson, R. Brian; Whitehead, Neil L. (eds). War in the tribal zone: Expanding states and indigenous warfare. Santa Fe; New Mexico: School of American Research Press, 1992. Pp. 127-150.

Wimmer, Andreas. Herder's Heritage and the Boundary-Making Approach: Studying Ethnicity in Immigrant Societies // Sociological Theory. 2009. Vol. 27. No. 3. Pp. 244-270. 
Wobeser, [Peter H.]. Etwas von dem Wohnsitz der Cassuben in Pommern // Wöchentliche Nachrichten von neuen Landcharten, geographischen, statistischen und historischen Büchern und Sachen. 1779. Vol. 7. No. 23. June 7. Pp. 182-183.

Wolf, Eric R. Europe and the people without history. Berkeley; Los Angeles: University of California Press, 1982. $503 \mathrm{p}$.

Гильфердинг, Александр Федорович. Остатки Славян на южном берегу Балтийского Моря. СПб., 1862; Дуличенко, Александр Дмитриеич. К незатухающему спору о словинцах (еще один скромный голос) // Rocznik Gdański. 1995. Vol. 55. No 1. Pp. 83-91.

Information about the article:

Author: Filip, Mariusz - PhD in Ethnology and Cultural Anthropology, Adam Mickiewicz University, Poznan, Poland, mfilip@amu.edu.pl; OrcID https://orcid.org/0000-0002-1992-0929

Title: A tribe after all? The problem of Slovincians' identity in an anthropological approach

Summary: The question about the (non)existence of Slovincians has been one of the more intriguing issues in Slavic studies. Slovincians, discovered initially as an "ethnic group" (Hilferding, 1862), was 130 years later rejected as a "fiction" (Szultka, 1992). Assimilating the lessons of the epistemological turn, which suggests shifting the emphasis from "whether" to "how" does anything exist, I critically examine the foundations and significance of the argument that there never was any "ethnic group" of Slovincians (in modern period) since there was no such a tribe in early medieval times. In the first part of the paper, I reveal that Szultka's claim is supported by very limited evidence following the conceptually limited ("archaeological") naturalist notion of tribe. In the second part, after familiarizing the reader with an antinaturalist anthropological notion of tribes as "secondary phenomena", I seek to demonstrate that in the course of history, the Slovincians were constantly tribalized on the material and symbolic level by the Germans and the Poles (and some other actors of Slavic identity). Even if to be a tribe does not entail to be an ethnic group, Slovincians may be a fiction only in terms of social construction or making of.

Keywords: Slovincians, Kashubians, tribe, tribalization, fiction, identity

\section{References:}

Adamczyk, Dariusz. Od dirhemów do fenigów: Reorientacja bałtyckiego systemu handlowego na przełomie X i XI wieku [From dirhem to fenig. Reorientation of the Baltic system of trade at the turn of $10^{\text {th }}$ and $11^{\text {th }}$ century], in Średniowiecze Polskie i Powszechne. 2007. Vol. 4. Pp. 15-27. (in Polish).

Anton, Karl Gottlob. Erste Linien eines Versuches über die alten Slawen Ursprung, Sitten, Gebräuche, Meinungen und Kenntnisse [First Lines of an Essay on the Origin, Manners, Customs, Opinions, and Knowledge of the ancient Slavs]. Leipzig: Adam Friedrich Böhme Publ., 1783. 178 p. (in German).

Appadurai, Arjun. Putting hierarchy in its place, in Cultural Anthropology. 1988. Vol. 3. No. 1. Pp. 36-49. Ardener, Edwin. Language, Ethnicity and Population, in Journal of the Anthropological Society of Oxford. 1972. Vol. 3. No. 3. Pp. 125-132.

Ardener, Edwin. Tożsamość i utożsamienie [Identity and Identification], in Mach, Zdzisław; Paluch, Andrzej K. (eds). Sytuacja mniejszościowa i tożsamość [Minority Situation and Identity]. Krakow: Wydawnictwo Uniwersytetu Jagiellońskiego Press, 1992. Pp. 21-42. (in Polish).

Astuti, Rita. «The Vezo Are Not a Kind of People»: Identity, Difference, and Ethnicity among a Fishing People of Western Madagascar, in American Ethnologist. 1995. Vol. 22. No. 3. Pp. 464-482.

Barth, Fredrik (ed.). Ethnic Groups and Boundaries: The Social Organization of Culture Difference. Bergen; Oslo: Universitetsforlaget Publ.; London: George Allen and Unwin Publ., 1969. 153 p.

Bernoulli, Johann. Reisen durch Brandenburg, Pommern, Preußen, Curland, Rußland und Pohlen, in den Jahren 1777 und 1778 [Travels through Brandenburg, Pomerania, Prussia, Courland, and Poland, in the years 1977 and 1778]. Leipzig: Caspar Fritsch Publ., 1779. 298 p. (in German).

Bhabha, Homi. Of Mimicry and Man: The Ambivalence of Colonial Discourse, in October. 1984. Vol. 28. Pp. 125-133.

Bolduan, Tadeusz. Losy społeczne i polityczne Słowińców w Klukach w latach 1945-1975. Próba oceny [The social and political fate of the Slovincians in Kluki over the years 1945-1975. An attempt of evaluation], in Treder, Jerzy (ed.). Studia kaszubsko-stowińskie. Materiały z II Konferencji Słowińskiej (Leba 11-13.05.1992) [The Kaschubian-Slovincian Studies. Proceedings of the Second Slovincian Conference (Leba, May 11-15, 1992)]. Leba: Zrzeszenie Kaszubsko-Pomorskie Publ., 1992. Pp. 9-30. (in Polish).

Bourdieu, Pierre. What makes a social class? On the theoretical and practical existence of groups, in Berkeley Journal of Sociology. 1987. Vol. 32. Pp. 1-17. 
Brüggeman, Ludewig Wilhelm. Ausführliche Beschreibung des gegenwärtigen Zustandes des Königl. Preußischen Herzogthums Vor- und Hinter-Pommern. Erster Theil welcher außer der allgemeinen Einleitung die Beschreibung des Preußischen Vorpommern enthält [Thorough Description of the Present Condition of the Royal Prussian Duchy of Hither and Farther Pomerania. The first part, which contains, besides the general introduction, the description of Prussian Hither Pomerania]. Stettin: H. G. Effenbart Publ., 1779. 276 p. (in German).

Buko, Andrzej. The Archaeology of Early Medieval Poland: Discoveries - Hypotheses - Interpretations. Leiden; Boston: Brill Publ., 2008. 475 p.

Carsten, Janet. The Politics of Forgetting: Migration, Kinship and Memory on the Periphery of the Southeast Asian State, in Journal of the Royal Anthropological Institute. 1995. Vol. 1. No. 2. Pp. 317-335.

Cassirer, Ernst. An Essay on Man: An Introduction to a Philosophy of Human Culture. New York: Doubleday Anchor Books Publ., 1944. 294 p.

Cohen, Anthony P. The symbolic construction of community. London; New York: Routledge Publ., 1985. $128 \mathrm{p}$.

Connerton, Paul. Seven Types of Forgetting, in Memory Studies. 2008. Vol. 1. No. 1. Pp. 59-71.

Curta, Florin. The Making of the Slavs: History and Archaeology of the Lower Danube Region c. 500-700. Cambridge: Cambridge University Press, 2001. 463 p.

Czarnik, Andrzej. Gardna Wielka. Słupsk: Pomorska Akademia Pedagogiczna Press, 2001. 202 p. (in Polish). Dulichenko, Aleksandr Dmitrievich. K nezatukhayushchemu sporu o slovintsakh (eshche odin skromniy golos) [For the not-expiring dispute about Slovincians (another humble voice)], in Rocznik Gdański. 1995. Vol. 55. No. 1. Pp. 83-91. (in Russian).

Fabian, Johannes. Time and the Other: How Anthropology Makes its Object. New York: Columbia University Press, 1983. 205 p.

Filip, Mariusz. Od Kaszubów do Niemców. Tożsamość Stowińców z perspektywy antropologii historii [From Kashubians to Germans. Slovincians'Identity from the Perspective of the Anthropology of History]. Poznan: Wydawnictwo Nauka i Innowacje Publ., 2012. 237 p. (in Polish).

Frank, Andre Gunder. The Development of Underdevelopment, in Monthly Review. September, 1966. Vol. 18. No. 4. Pp. 17-31.

Frank, Erwin H. Etnicidad: contribuciones etnohistóricas a un concepto difícil [Ethnicity: The Ethnohistorical Contributions to a Difficult Concept], in Jorna, Peter; Malaver, Leonor; Oostra, Menno (eds). Etnohistoria del Amazonas [Ethnohistory of the Amazon]. Quito: Abya-Yala Publ., 1991. Pp. 63-81. (in Spanish).

Fried, Morton H. On the Concepts of «Tribe» and «Tribal Society», in Transactions of the New York Academy of Sciences. 1966. Vol. 28. No. 4. Pp. 527-540.

Geary, Patrick J. Before France and Germany: The Creation and Transformation of the Merovingian World. New York: Oxford University Press, 1988. 259 p.

Geertz, Clifford. Thick Description: Toward an Interpretive Theory of Culture, in The Interpretation of Cultures: Selected Essays. New York: Basic Books Publ., 1973. Pp. 3-30.

Gow, Peter. «Ex-Cocama»: Transforming Identities in Peruvian Amazonia, in Fausto, Carlos; Heckenberger, Michael (eds). Time and Memory in Indigenous Amazonia: Anthropological Perspectives. Gainesville: University Press of Florida, 2007. Pp. 194-215.

Hacking, Ian. The Social Construction of What? Cambridge: Harvard University Press, 1999. 261 p.

Haken, [Christian Wilhelm]. Etwas von den Pommerschen Cassuben (...) zu Stolpe in Hinter-Pommern [Somewhat about the Pomeranian Kashubians (...) by Słupsk in Farther Pomerania], in Wöchentliche Nachrichten von neuen Landcharten, geographischen, statistischen und historischen Büchern und Sachen. 1779. Vol. 7. No. 24. June 14. Pp. 189-193. (in German).

Haken, [Christian Wilhelm]. Beschluß der Nachricht (...) von den Cassuben [Resolution of the Message (...) about Kashubians], in Wöchentliche Nachrichten von neuen Landcharten, geographischen, statistischen und historischen Büchern und Sachen. 1779. Vol. 7. No. 25. June 21. Pp. 197-204. (in German).

Hastrup, Kirsten. Nature as Historical Space, in Folk. Journal of the Danish Ethnographic Society. 1989. Vol. 31. Pp. 5-20.

Hechter, Michael. Internal Colonialism: The Celtic Fringe in British National Development, 1536-1966. Berkeley: University of California Press, 1975. 361 p.

Herder, Johann Gottfried. J. G. Herder on Social and Political Culture. Ed. by Barnard, Frederick M. London: Cambridge University Press, 1969. 329 p. 
Hilferding, Aleksander. Ostatki Słowian na południowym brzegu Bałtyckiego Morza [The Last Remnants of the Slavs on the Southern Coast of the Baltic], in Kolberg, Oskar (ed.). Pomorze [Pomerania]. Krakow: Polskie Wydawnictwo Muzyczne Publ.; Warszawa: Ludowa Spółdzielnia Wydawnicza Publ., 1965. Pp. 311-452. (in Polish).

Hilferding, Aleksandr Fyodorovich. Ostatki slavyan na yuzhnom beregu Baltiyskogo morya [The Last Remnants of the Slavs on the Southern Coast of the Baltic]. St. Petersburg: Imperatorskoe Russkoe geograficheskoe obshhestvo Publ., 1862. 191 p. (in Russian).

Hinze, Friedhelm. Slovinzische Fischzugnamen von Garder See in Hinterpommern. Nachleben und Etymologie slovinzische Namen [Slovincian names for fishing plots of the Lake Gardno in Farther Pomerania. The Afterlife and Etymology of Slovincian Names], in Zeitschrift für Slawistik. 1970. Vol. 15. No. 3. Pp. 386-392. (in German).

Hirsch, Eric; Stewart, Charles. Introduction: Ethnographies of Historicity, in History and Anthropology. 2005. Vol. 16. No. 3. Pp. 261-274.

Knoop, Otto. Etwas von den Kaschuben [Somewhat about the Kashubians], in Unsere Heimat. Beilage zur Kösliner Zeitung. 1925. No. 1 (January 31), no. 2 (February 21), no. 4 (March 28), no. 6 (April 27). (in German).

Koblischke, Julius. Der Name «Slovinzen» [ The Name «Slovincians»], in Mitteilungen des Vereins für Kaschubische Volkskunde. 1908. Vol. 1. No. 1. Pp. 12-14. (in German).

Kroeber, Alfred L. Nature of the land-holding group, in Ethnohistory. 1955. Vol. 2. Pp. 303-314.

Krofey, Szyman. Duchowne piesnie D. Marcina Luthera y ynßich naboznich męzow. Zniemieckiego w Slawięsky ięzik wilozone [Spiritual Songs by Dr. Martin Luther and Other Pious Christians. From German to the Slavic language translated]. Gdańsk, 1586. 158 p. (in Kashubian \& Polish).

Lévi-Strauss, Claude. The Elementary Structures of Kinship. Boston: Beacon Press, 1969. 541 p.

Lévi-Strauss, Claude. Tristes tropiques. New York: Criterion Books Publ., 1961. 404 p.

Linnekin, Jocelyn; Poyer, Lin (eds). Cultural Identity and Ethnicity in the Pacific. Honolulu: University of Hawaii Press, 1990. 323 p.

Lorek, Gottlieb Leberecht. Charakterystyka Kaszubów znad Łeby. Z rysunkami kaszubskich strojów ludowych / Zur Charakteristik der Kassuben am Leba-Strome. Mit einer Abbildung kassubischer Volkstrachten [To the characteristics of the Kashubians on the Łeba river. With picture of Kashubian folk costumes], in Borzyszkowski, Józef (ed.). Niemcy o Kaszubach w XIX wieku. Obraz Kaszubów w pracach G. L. Lorka, W. Seidla i F. Tetznera / Deutsche Berichte über die Kaschuben im 19. Jahrhundert. Das Bild der Kaschuben in den Abhandlungen von G. L. Lorek, W. Seidel und F. Tetzner [German reports on the Kashubians in the $19^{\text {th }}$ century. The picture of the Kashubians in the treatises of G. L. Lorek, W. Seidel und F. Tetzner]. Gdańsk: Instytut Kaszubski Press, 2009. Pp. 37-78, 83-126. (in Polish \& German).

Lorentz, Friedrich. Nochmals der Name «Slovinzen» [Once more the Name «Slovincians»], in Mitteilungen des Vereins für kaschubische Volkskunde. 1908. Vol. 1. No. 1. Pp. 14-16. (in German).

Lowenthal, David. The Past is a Foreign Country. Cambridge: Cambrid.ge University Press, 1985. 489 p.

Lozoviuk, Petr. The Problems of the Issue of «Ethnic Indifference» in the Czech Language Milieu, in Uherek, Zdeněk (ed.). Ethnic studies and the urbanized space in social anthropological reflections. Praha: Institute of Ethnology of the Academy of Sciences of the Czech Republic Press, 1998. Pp. 41-47.

Morgan, Lewis H. Ancient Society. Or Researches in the Lines of Human Progress from Savagery through Barbarism to Civilization. Chicago: C. H. Kerr Publ., 1877. 570 p.

Nowak, Oskar; Liczbińska, Grażyna; Piontek, Janusz. Opportunity for the Operation of Natural Selection in a Contemporary Local Population (The Case of Slovincians, Poland), in Advances in Anthropology. 2013. Vol. 3. No. 3. Pp. 121-126.

Obrębski, Józef. Problem grup etnicznych w etnologji i jego socjologiczne ujęcie [Problem of Ethnic Groups in Ethnology and its Sociological Interpretation], in Przeglad Socjologiczny. 1936. Vol. 4. Pp. 177-195. (in Polish).

Pontanus [=Brüggeman(n), Michael]. Parvus Catechismus D. Martini Lvtheri Germanica - Vandalicus = Der kleine Catechißmus D. Martini Lutheri / Deutsch vnnd Wendisch gegen einander gesetzt. Mit anhange der Sieben Bußpsalmen König DAVIDS = Mały Catechism D Marciná Lutherá Niemiecko Wándalski ábo Stowięski [The Small Cathechism by Dr. Martin Luther German Vandalic or Slavic]. Gdansk: Jerzy Rhet Publ., 1643. 68 p. (in Kashubian \& Polish).

Rybicki, Hieronim. Nazywano ich Stowińcami [They Were Called Slovincians]. Slupsk: Wyższa Szkoła Pedagogiczna Publ., 1995. 278 p. (in Polish). 
Rybicki, Hieronim. Nazywano ich Stowińcami. Cz. 2. Wybór źródeł [They Were Called Slovincians. Part II: The Chosen Sources]. Gdansk: Instytut Kaszubski Press; Wejherowo: Muzeum Piśmiennictwa i Muzyki Kaszubsko-Pomorskiej Publ., 2003. 262 p. (in Polish).

Sahlins, Marshall D. Islands of History. Chicago; London: The University of Chicago Press, 1985. 180 p.

Sahlins, Marshall D. The Original Affluent Society, in Stone Age Economics. Chicago: Aldine-Atherton Publ., 1972. Pp. 1-39.

Sahlins, Marshall D.; Service, Elman R. (eds). Evolution and Culture. Ann Arbor: University of Michigan Press, $1960.131 \mathrm{p}$.

Scott, James C. Weapons of the Weak: Everyday Forms of Peasant Resistance. New Haven; London: Yale University Press, 1985.389 p.

Shirokogoroff, Sergei Mikhailovich. Psychomental complex of the Tungus. London: Kegan Paul Publ., 1935. $469 \mathrm{p}$.

Ślaski, Kazimierz. Dzieje ziemi kołobrzeskiej do czasów jej germanizacji [History of the Kołobrzeg Land until its Germanization]. Torun: Towarzystwo Naukowe Publ., 1948. 116 p. (in Polish).

Stelmachowska, Bożena. Stowińcy i ich kultura [The Slovincians and their Culture]. Poznan: Wydawnictwo Poznańskie Publ.; Slupsk: Polskie Towarzystwo Historyczne Publ., 1963. 153 p. (in Polish).

Szultka, Zygmunt. Studia nad rodowodem i językiem Kaszubów [Studies on the Ancestry and Language of the Kashubians]. Gdansk: Muzeum Piśmiennictwa i Muzyki Kaszubsko-Pomorskiej w Wejherowie Publ., 1992. 187 p. (in Polish).

Taussig, Michael. Mimesis and Alterity: A Particular History of the Senses. New York: Routledge Publ., 1993. 299 p.

Tonkin, Elizabeth; McDonald, Maryon; Chapman, Malcolm (eds). History and Ethnicity. London: Routledge Publ., 1989. 240 p.

Treder, Jerzy. Komu może przeszkadzać etnonim Słowińcy? [Who might be disturbed by the ethnonym Slovincians?], in Czarnik, Andrzej (ed.). Obrazy Ziemi Stupskiej. Społeczeństwo - administracja — kultura. Materiały z VII Konferencji Kaszubsko-Pomorskiej, Słupsk 5-6 grudnia 2002 [Images of the Stupsk Land. Society - administration - culture. Proceedings of the Eighth Kashubian-Pomeranian Conference, Słupsk, December 5-6, 2002]. Slupsk: Starostwo Powiatowe Publ., 2003. Pp. 59-70. (in Polish).

Wachowiak, Bogdan (ed.). Źródta do kaszubsko-polskich aspektów dziejów Pomorza Zachodniego do roku 1945 [Sources for Kashubian-Polish Aspects of the History of Western Pomerania until 1945]. Vol. I: Pomorze Zachodnie pod rządami książąt plemiennych i władców z dynastii Gryfitów (990-1121-1637-1648/1653) [Western Pomerania under the Rule of Tribal Princes and Dukes of the Griffin Dynasty (990-1121-16371648/1653)]; Vol. II: Pomorze Zachodnie w państwie brandenbursko-pruskim (1653-1815) [Western Pomerania in the Brandenburg-Prussian State (1653-1815)]. Szultka, Zygmunt (pub.). Poznan: Wydawnictwo Poznańskie Publ.; Gdansk: Zrzeszenie Kaszubsko-Pomorskie Publ., 2006. 745 p.; 580 p. (in Polish).

Wachtel, Nathan. Men of the Water: The Uru Problem (Sixteenth and Seventeenth Centuries), in Murra, John V.; Wachtel, Nathan; Revel, Jacques (eds). Anthropological History of Andean Polities. Cambridge: Cambridge University Press, 1986. Pp. 283-310.

Wagner, Roy. Are there Social Groups in the New Guinea Highlands?, in Leaf, Murray J. (ed.). Frontiers of Anthropology: An Introduction to Anthropological Thinking. New York: D. Van Nostrand Company Publ., 1974. Pp. 95-122.

White, Hayden. Metahistory: The Historical Imagination in Nineteenth-Century Europe. Baltimore: Johns Hopkins University Press, 1973. 448 p.

Whitehead, Neil L. Tribes Make States and States Make Tribes: Warfare and the Creation of Colonial Tribes and States in Northeastern South America, in Ferguson, R. Brian; Whitehead, Neil L. (eds). War in the tribal zone: Expanding states and indigenous warfare. Santa Fe; New Mexico: School of American Research Press, 1992. Pp. 127-150.

Wimmer, Andreas. Herder's Heritage and the Boundary-Making Approach: Studying Ethnicity in Immigrant Societies, in Sociological Theory. 2009. Vol. 27. No. 3. Pp. 244-270.

Wobeser, [Peter H.]. Etwas von dem Wohnsitz der Cassuben in Pommern [Somewhat about the residence of the Kashubians in Pomerania], in Wöchentliche Nachrichten von neuen Landcharten, geographischen, statistischen und historischen Büchern und Sachen. 1779. Vol. 7. No. 23. June 7. Pp. 182-183 (in German). Wolf, Eric R. Europe and the people without history. Berkeley; Los Angeles: University of California Press, 1982. $503 \mathrm{p}$. 